\title{
Big Data Analytics in the German Banking Sector Using the Example of
}

\section{Retail Banking}

\author{
Kevin Hock ${ }^{1}$, Carsten Giebe ${ }^{2,3}$ \\ ${ }^{1}$ FOM - University of Applied Sciences, Berlin, Germany \\ ${ }^{2}$ Hungarian University of Agriculture and Life Sciences - Faculty of Economic Science | Doctoral School in Management and \\ Organizational Sciences, Kaposvár, Hungary \\ ${ }^{3}$ Hochschule Macromedia - University of Applied Sciences, Berlin, Germany
}

\begin{abstract}
Due to digitalization, the banking sector has been undergoing massive change in Germany for years. The causes are the rapid technological progress, regulation and supervision, the low-interest phase and demographic change. The future world of work will be characterised by digitalization and automation. These changes will have an impact on how bank customers demand, evaluate and ultimately purchase financial services. This paper examines the impact of digitalization on the entire German banking market and shifts the focus to big data analytics as a possible means of improving existing business areas with innovative approaches. The retail banking business is used as an example to show how Big Data Analytics is already being used by banks and what opportunities there are for further development. This quantitative research summarises the analysis of German banking groups using real key figures. The aim is to identify approaches to how banks can respond to the challenges of the market environment beyond cost-cutting measures. The relevance of the research's findings can be useful for academics looking at big data analytics and digital transformation in general in Germany's banking centre and looking for real examples from practice.
\end{abstract}

KEYWORDS: Big Data Analytics, German banking sector, Digital Transformation

JEL-Codes: D41, G21, M21

\section{INTRODUCTION}

According to a study conducted by the International Data Corporation (IDC) in 2020 as part of IDC's Spending Guides, the banking industry is the industry with the highest market share in terms of the Big Data analytics market in a global comparison. At 15.5 percent, its estimated share of the market volume was significantly higher than that of the runner-up - the telecommunications industry with a market share of 11.6 percent (see Figure 1).

Estimated share of the global big data analytics market by industry in 2020

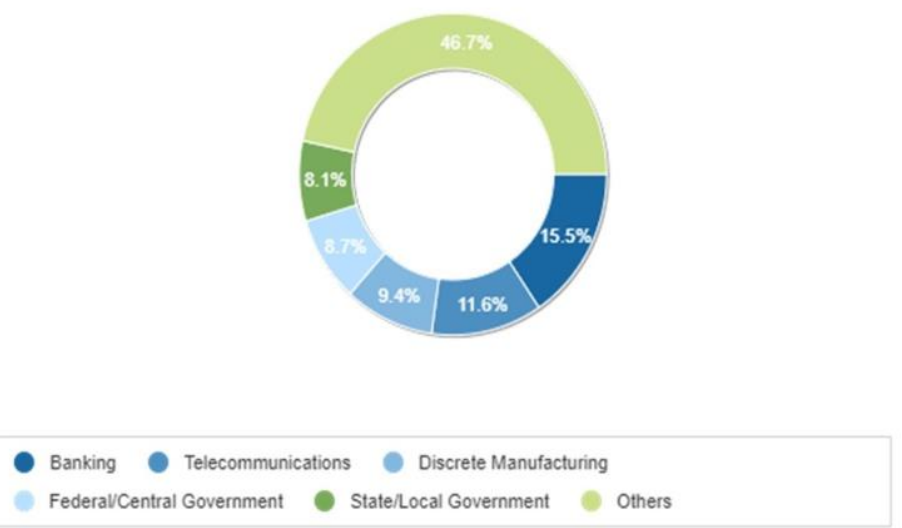

Figure 1: Estimated share of the global big data analytics market by industry in 2020

Source: IDC, Big Data and Analytics Spending Guide - Forecast (2020) 


\section{"Big Data Analytics in the German Banking Sector Using the Example of Retail Banking"}

Trelewicz attributes the high relevance of big data analytics in the banking industry to the presence of the typical big data characteristics - the "3Vs" - in the financial environment: volume, velocity and variety of data. She sees the constantly changing regulatory requirements and reporting standards as drivers for the continuous development of new data sources. Accordingly, the banking industry is a prime example of the integration of big data analytics solutions into existing business models (Trelewicz, 2017). However, there are also opposing opinions in the researched studies. For example, the potential offered by business analytics is often insufficiently implemented in Germany (Gronau et al., 2016).

The authors Au and Hiese also emphasise the importance of two other "Vs" in the banking industry: validity and value of the data. With modern analytical methods, the use of big data is already widespread in the German banking industry. In the retail sector - the private customer business - big data and its analysis provide valuable insights into customers and their product and service wishes. It is worthwhile for banks to further develop the introduction of big data analytics and to align existing processes accordingly (Au \& Hiese, 2021).

According to Moormann, the integration of big data analytics into business processes, coupled with general technological progress, is leading to the biggest structural upheaval the German banking industry has ever experienced. At the same time, the banking sector is operating in a difficult market environment. A high market penetration has already been achieved with standard products such as the credit business, which is driving the banks towards innovative but also riskier business fields. The disappearance of entry barriers is also leading to growing competition in established business areas. Financial technology companies and non-banks would be able to approach the existing customers of an established bank directly via the internet; a dense branch network would no longer be a prerequisite. At the same time, cost pressure in the current low-interest environment is triggering cost-cutting measures such as the downsizing of the branch network (Moormann, 2000).

Menrad cites changing customer requirements as an additional challenge. According to his analyses, German bank customers are developing hybrid channel behaviour and demand situational communication across all channels. German banks are forced to transform their traditional approach management into omnichannel management (Menrad, 2020).

The access to and use of digital offers of financial services is furthermore influenced by socio-economic factors, according to Conrad et al. Socio-economic factors are, for example, level of education, income, age or internet literacy (Conrad et al., 2018). Here, a further conceptual need for credit institutions can be identified.

Giebe and Schulz (2021c) have already analysed the effects of these developments for the savings banks and cooperative banks. It was found that both bank types have equally implemented cost-cutting measures in the form of job cuts and branch closures. At the same time, the authors attest to the banks' top management being too hesitant in defining a digital strategy. The one-sided focus on cost-cutting measures is no longer appropriate in the light of digitalization. The authors identified the use and expansion of big data analytics as a possible answer to the challenges presented in the banking market (Giebe \& Schulz, 2021c).

\section{LITERATURE REVIEW}

In order to describe the German banking landscape and to examine the challenges and opportunities of digitalization - especially with regard to big data analytics - a literature search was conducted according to two main categories.

The first category contains literature that addresses the challenges and effects of digitalization on the German banking market. The search algorithm initially used links the terms "banking/bank" with "digitalization/digitization" or "big data" and "germany/deutschland". The focus was on publications in academic journals and relevant specialist literature from 2010 onwards in order to be able to make a well-founded statement about the current developments and challenges of digitalization. About 1,250 search results were found using the EBSCO Discovery Service. An analogous search in Google Scholar yielded ten times that amount of results, of which, however, many publications turned out to be too unspecific for this research work. By replacing the term "banking" with the terms "savings banks", "cooperative banks" and "private banks", the modified search algorithm returned additional relevant literature describing the respective German bank types in detail. The German search terms were replaced accordingly. The publications by Moormann, Schädle, Menrad as well as Giebe and Schulz (2021a, 2021b, 2021c) were decisive for the assessment of the German banking landscape in this paper.

In the second category, the focus is on the use of big data analytics in the German banking sector. A current study by KPMG on data analytics in retail banking served as an introduction and provides an overview of the business cases that are already covered by big data analytics in the banking sector. Individual banks also made their own publications on big data analytics, such as 


\section{"Big Data Analytics in the German Banking Sector Using the Example of Retail Banking"}

Trelewicz for Deutsche Bank and Au and Hiese for Commerzbank. The Sparkassen-Finanzgruppe in particular is open about its use of data analytics in retail banking and makes relevant material available via its own communication platforms. The explanations and diagrams of S Rating und Risikosysteme $\mathrm{GmbH}$, the central data analytics service provider of the savings banks, were very helpful. The interviews with Christian Damaschke (CEO of S Rating und Risikosysteme GmbH) and Malte Lange (Product Owner Data Analytics, Finanz Informatik) on the current and future developments with regard to data analytics in the Sparkassen-Finanzgruppe also serve as an example of data analytics applications in the banking industry in the German banking centre. Damaschke \& Giebe (2020) can also be listed here.

\section{METHODOLOGY}

The aim of this quantitative research work is to provide an overview of the German banking sector and the current market environment in order to then work out the challenges and opportunities with regard to digitalization and to highlight possible innovations through the use of big data analytics. For this purpose, empirical studies from scientific literature as well as articles, interviews and available publications of individual German banks themselves will be used. Using typical key figures from the banking environment, the developments in the German banking market up to 2019 are statistically evaluated and the influence of big data analytics on the developments of these key figures is discussed.

To test the hypotheses, the developments of the key figures for the years 2003 to 2019 were presented graphically in each case. The direction of each development can be read from these visualisations. To test the significance of the assumed positive or negative trend, the correlation between the time in years and the respective key figure was determined as a test statistic and tested to see whether it is significantly different from zero. Depending on the direction of the suspected trend, either a left-hand or right-hand test was then carried out. Across all tests, the required significance level remained fixed at $\alpha=0.05$.

The rank correlation coefficient according to Spearman was used as a correlation measure. This is suitable for the investigation of time series, since only a monotonous temporal correlation is assumed and the type of correlation, such as a linear increase or decrease, does not have to be specified. The visualisations were generated and the data analysed using the programming language $\mathrm{R}$ and ggplot2.

\section{HYPOTHESES}

To structure this research, the following hypotheses about developments in the German banking sector are put forward and examined:

1. $H_{0}^{1}$ : The number of bank employees in Germany has changed significantly.

2. $H_{0}^{2}$ : The number of credit institutions in Germany has changed significantly.

3. $H_{0}{ }^{3}$ : The operating result of credit institutions in Germany has changed significantly.

4. $\quad H_{0}^{4}$ : The balance sheet total of credit institutions in Germany has changed significantly. 5 .

5. $H_{0}{ }^{5}$ : The cost-income ratio of credit institutions in Germany has changed significantly.

6. $H_{0}^{6}$ : The use of big data analytics had a measurable impact on the development of these indicators.

The period under consideration is the years 2003 to 2019 across all hypotheses. The period is deliberately chosen broadly in order to compare long-term trends with short-term developments in recent years.

\section{German Banks in the Age of Digitalization}

The German banking market can be divided into three sectors, which is why it is referred to as the three-pillar model of the German banking system (see Figure 2). This structure makes the German banking system unique (Behr \& Schmidt, 2015; Komorowski, 2020). 


\section{The three pillars of the German banking system}
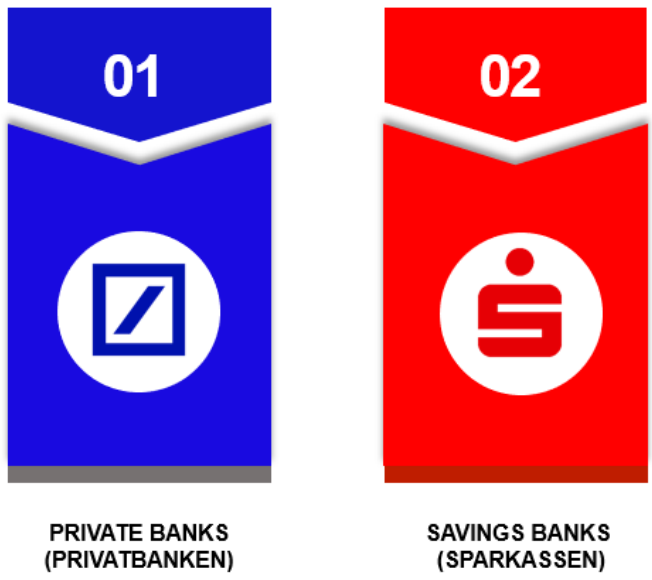

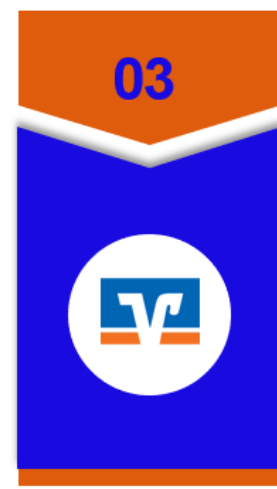

COOPERATIVE BANKS (GENOSSENSCHAFTSBANKEN)

Figure 2: Own illustration, The Three Pillars of the German Banking System

The first pillar symbolises the private banks such as Deutsche Bank, Commerzbank and UniCredit Bank. They generally have legal forms under private law and are often listed on the stock exchange. The large private banks originally focused on corporate banking, i.e. serving international industrial companies and large medium-sized enterprises as well as wealthy private individuals in the private banking sector. Today, the majority of private banks are universal banks. They offer their financial services and products to a wide range of private and corporate clients. The business remains traditionally designed to maximise profits (Giebe \& Schulz, 2021c).

Comparable to this are the financial technology companies as new market participants (fintechs). Fintechs are creating serious competitors for entire product areas (Drummer et al., 2016). Schädle also assigns FinTechs to the first pillar, as they are predominantly profit-oriented and privately owned (Schädle, 2021).

The second pillar includes the savings banks and Landesbanken. They are institutions under public law in municipal ownership, such as districts and independent cities. Supra-regionally, the savings banks are organised in regional associations that represent the interests of their members. The regional principle of the Savings Banks results from this regional rooting. The business areas of the individual institutions are strictly demarcated from one another, so that apart from a few local mixtures, no overlapping of business areas is permitted. This avoids internal competition for existing and new customers. As universal banks, savings banks serve both private and corporate customers. In distinction to private banks, however, savings banks are increasingly assigned to retail banking, as they serve the mass market with standardised financial products. Savings banks are also subject to the principle of non-profit. According to this principle, an adequate profit is sufficient, so that parts of the profit must be used for charitable purposes in the region. This principle is derived from the public mandate to provide the inhabitants of a region with free access to financial products, to promote savings and asset accumulation among the population, and to support the regional middle class (Giebe \& Schulz, 2021b; Giebe \& Schulz, 21c).

The third and final pillar is represented by the cooperative banks, which include, for example, the Volks- and Raiffeisenbanken. The customers of a cooperative bank are usually also shareholders. Shareholders are customers who participate in the credit institution in the form of cooperative shares. According to their statutes, their goal is the economic promotion of their cooperatives through joint business operations. Like the savings banks, they belong to the retail banks and are also organised in regional associations and subject to the regional principle (Giebe \& Schulz, 2021a; Schädle, 2021). There are further studies that explicitly deal with cooperative banks. According to Arts, the challenges and threats from fintech companies described at the beginning also exist for the cooperative banking group due to increasing digitalization (Arts, 2016).

A comparison of the three pillars shows that the savings banks and Landesbanken held the largest share of the banking market in 2020 with 27.8 percent. The private banks together were almost nine percentage points worse represented in the market with 18.7 percent. The cooperative banks were comparatively far behind with 13.5 percent (see Figure 3 ). 


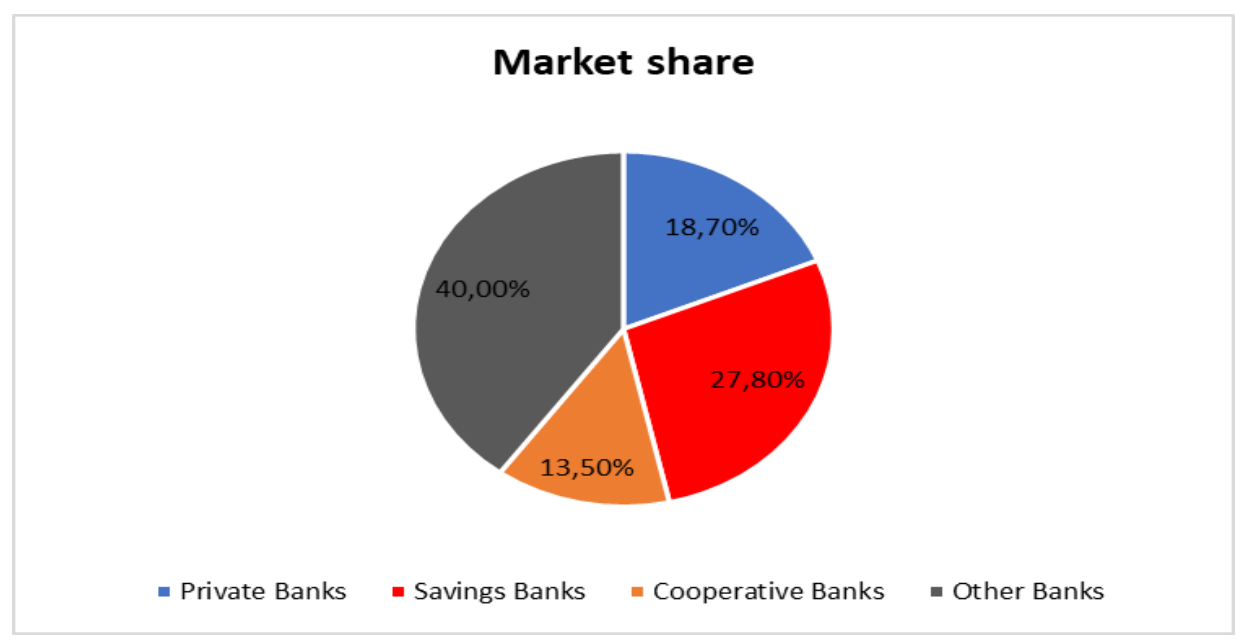

Figure 3: Own presentation, market shares of the banking groups in Germany by business volume in 2020

Source: Based on Statista Research Department, Market shares of the banking groups in 2020

\section{Challenges and opportunities of digitalization}

The authors Giebe and Schulz (2021c) see the German banking market in a state of flux due to the ongoing digital transformation. Banks are forced to come up with innovative product ideas in order to further expand their market share. A high market penetration has already been achieved with standard products. In addition, FinTechs and non-banks are pushing into the established business areas. The low interest rate environment also puts pressure on the lending business and triggers cost pressure on the banks, which leads to job and branch cuts (Wolgast, 2016; Giebe \& Schulz, 2021c).

On the customer side, market demands are also changing. As Moormann points out, customers' demands for quality and service have increased due to the spread of communication and information technologies (Moormann, 2000).

In this context, Menrad considers an omnichannel strategy to be without alternative from the banks' point of view in order to meet customer demands. He defines omnichannel banking as the simultaneous and synergetic management of all sales-relevant channels in order to offer the bank customer an optimal user experience. The customer himself decides along his customer journey through which touchpoints he wants to communicate with the bank (Menrad, 2020).

Kramer and Mendez Inclan (2019) come to a similar conclusion. They continue to see the development of cross-channel and self-contained customer communication as a field of development that poses challenges for German banks. With the consistent further development of big data analytics in the institutions, however, this is achievable. In their 2019 study, in which 85 per cent of the German retail banking market was surveyed and evaluated with regard to the use of data analytics, they examined the current situation in the German banking market. As the authors explain, data analytics is already established and in regular operation at most institutions. Among the banks surveyed, all emphasised the high potential of data analytics in private customer sales and stated that they gave consistent further development a high strategic priority. At the time of the study, data analytics methods were mainly used for existing customers across all product groups. The sales focus was on lead generation. The aim is to establish contacts with prospective customers who are very likely to become customers of the bank. However, the full leveraging of the data treasure trove of German retail banks has not yet been completed, as some sales departments are struggling to fully exploit the possibilities of digital sales (Kramer \& Mendez Inclan, 2019).

In addition, bank advisors often sell the products that bring the most commission or that advisors have on their target card. These products are not always optimal for clients. This can be questionable from an ethical point of view. Data analytics could provide a remedy here (Giebe et al., 2019).

\section{Relevance of Big Data in the banking business}

Today, Big Data can be found in almost every industry segment. Whether in the health industry or e-commerce, the benefits of Big Data have already been amply demonstrated. But large amounts of data do not generate added value by themselves. Only the combination of expert knowledge and the application of analytical methods can provide valuable impetus (Hammerström, 2018). Investment decisions in big data analytics are then often influenced by the desire to optimise existing business and become more 


\section{"Big Data Analytics in the German Banking Sector Using the Example of Retail Banking"}

competitive (Hammerström et al., 2019).

Trelewicz sees three key factors that turn data into Big Data in the banking industry:

- Volume: The generation, storage and processing of several terabytes of data - typically per day on international exchanges.

- Velocity: The speed at which data is generated and processed. In the trading environment, this already happens in real time.- Velocity: The speed at which data is generated and processed. In the trading environment, this already happens in real time.

- Variety: The heterogeneity of the data collected and processed, such as reference, market and trading data.

Tese three factors are known as the "3Vs" and represent a common definition of Big Data (Trelewicz, 2017). The authors Au and Hiese see two additional characteristics of Big Data in the banking industry:These three factors are known as the "3Vs" and represent a common definition of Big Data (Trelewicz, 2017).

The authors Au and Hiese see two additional characteristics of Big Data in the banking industry:

- Validity: The need for sufficient data quality to ensure the trustworthiness of the analysis results. Incomplete or erroneous data would therefore lead to dubious business cases and the waste of limited resources.

- Value: The monetisation of data and the creation of new business areas and cost reduction potentials. The mastery of data volumes is already a competitive differentiator.

They call this five-factor model the "5V model" (Au \& Hiese, 2020).

The "3Vs" Volume, Velocity and Variety can be found in the German banking industry and characterise the data in the German banking sector as Big Data. For the year 2020, the Deutsche Bundesbank shows more than 100 million current accounts across all institutions in the payment transaction and securities settlement statistics. Nearly 6.9 billion transfers and 11.6 billion direct debits were made via these accounts in Germany and abroad. Taken together, this resulted in an average of over 500 financial transactions per second (Deutsche Bundesbank, 2021).

The example of the Sparkassen-Finanzgruppe shows the heterogeneity of the data used. On the savings banks' own news platform Sparkassenzeitung, Damaschke (CEO of S Rating und Risikosysteme GmbH) commented in 2020 on the data sources that would foreseeably flow into the big data analytics models of the savings banks. According to him, in addition to customer master data and turnover data, customer behavioural data, regional market data and external address data as well as geo and transaction data but also documents and correspondence are relevant (Damaschke, 2020).

\section{Big data analytics in retail banking using the example of Sparkassen-DataAnalytics}

Using the example of the Sparkassen-Finanzgruppe, the use of Big Data Analytics methods in the private customer business of a credit institution will be examined in more detail.

Malte Lange (Productowner Data Analytics at Finanz Informatik) spoke about the use of Big Data Analytics in the Sparkassen-Finanzgruppe in 2020. According to him, data-based sales models are available to the institutions under the name Sparkassen-DataAnalytics. These mathematical-statistical models are developed with the help of predictive analytics processes on the basis of customer data from the approximately 50 million Sparkasse customers and make predictions about which customers will conclude certain financial products in the future. The use of savings bank data analytics leads to higher closing rates of up to 200 percent. The focus is on the economic benefit of these methods (Lange, 2020).

Data-driven product sales is still a young venture in the savings bank group. The standardised playout of Big Data models only took place in 2018 (S Rating und Risikosysteme GmbH, 2021).

Damaschke (CEO of S Rating und Risikosysteme GmbH) still sees potential for improvement in the accuracy of the selections and in the integration of data analytics in the entire approach management. In order to align the savings banks towards a common omnichannel strategy, he strives for the collection of customer behavioural data across all offline and online touchpoints of the savings bank (Damaschke, 2020).

S Rating und Risikosysteme describes how Sparkassen-DataAnalytics works on its own website. The traditional sales options such as mass advertising and expert selections are contrasted with data analytics selections. Accordingly, the prediction of affine customers for a financial product enables "one-to-one sales" by bundling the existing sales resources on a few relevant target group customers and thus efficiently deploying them. In the future, this approach (see Figure 4) is to be expanded into a "one-to-one 
distribution" so that each customer is individually offered the right product at the right time via the right channel (S Rating und Risikosysteme GmbH, 2021).

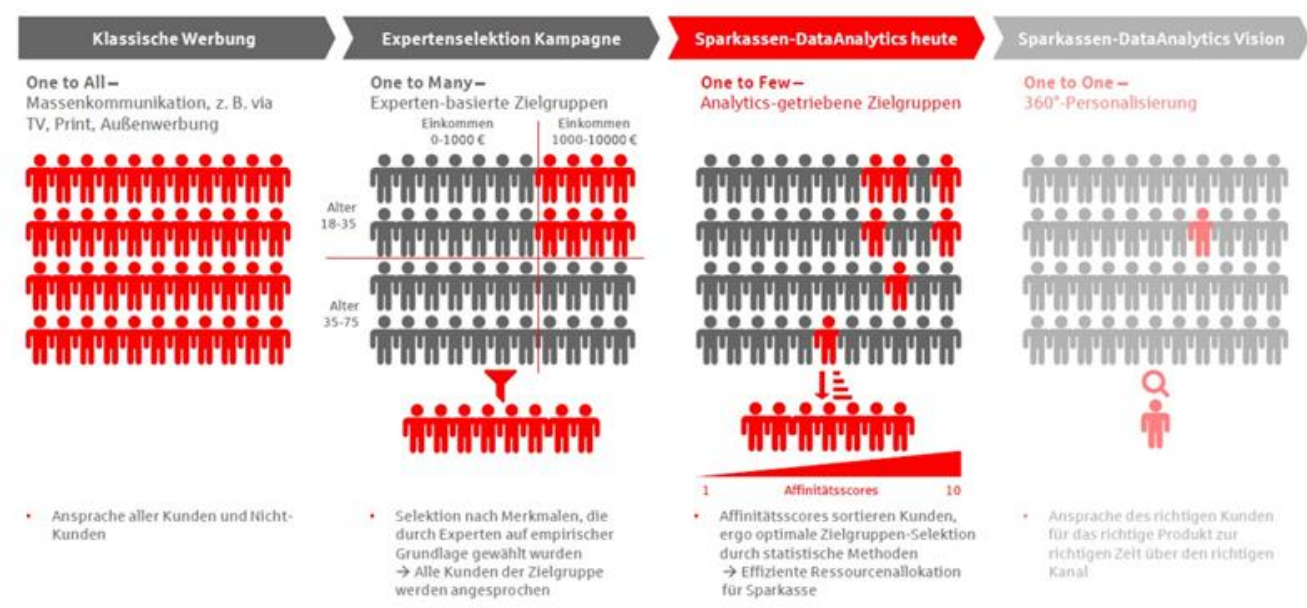

Figure 4: Sparkassen-DataAnalytics compared to traditional Savings Banks Sales

Source: SR, Sparkassen-DataAnalytics, 2021

\section{RESULTS}

While digitalization created new opportunities in retail banking, such as omnichannel and sales support through big data analytics, the traditional banking business remains under pressure in an environment of low interest rates and cost-cutting measures. The effects of these developments on the German banking market were as follows in the years 2003 to 2019.

\section{Developments in the German banking sector until 2019}

The number of employees in the German banking industry has declined sharply over the entire period under consideration, falling from over 700,000 employees in 2013 to just over 550,000 in 2019, i.e. a reduction of 50,000 employees on average every five years. Around 2015, the reduction in the workforce accelerated even further (see Figure 5).

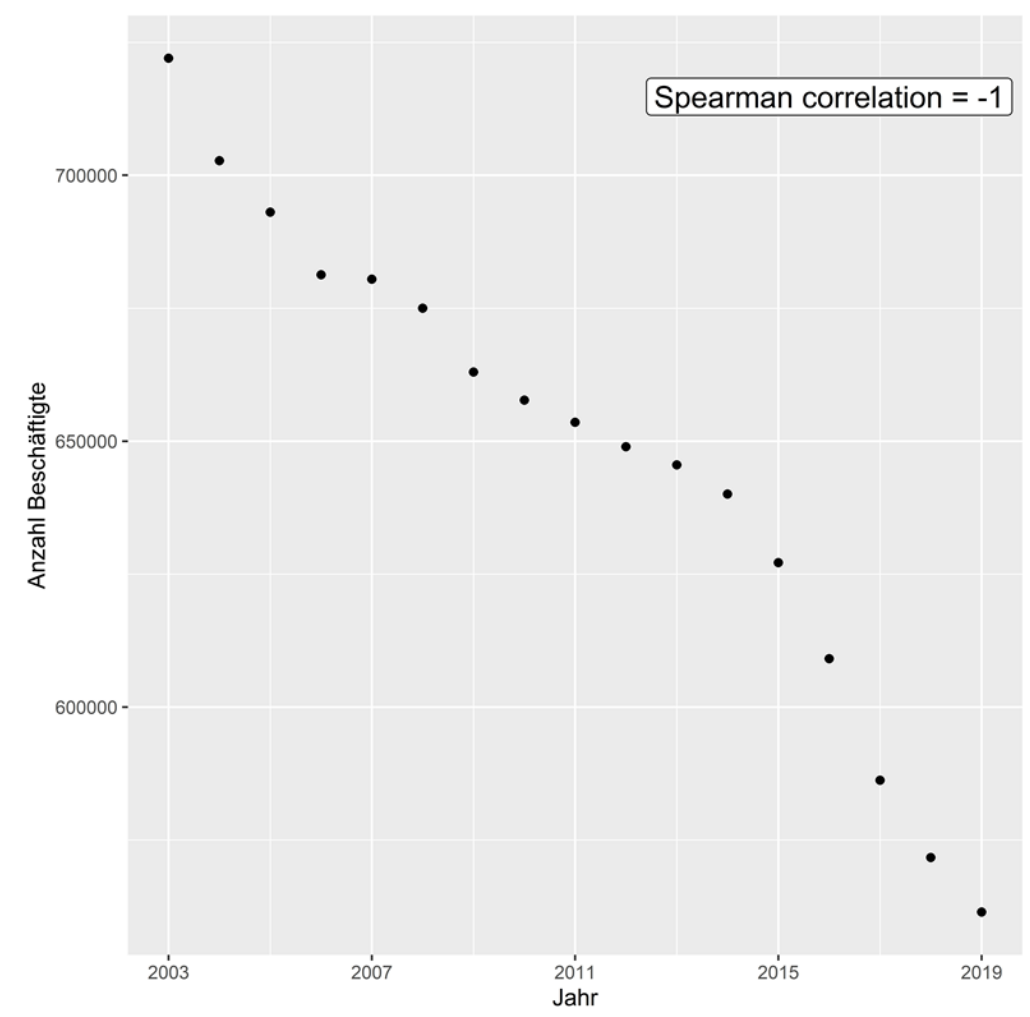

Figure 5: Own representation, development of the number of employees in the German banking industry from 2003 to 2019 
The number of employees in the period under consideration is strictly monotonically decreasing with a rank correlation coefficient of -1 and statistically significant, so the hypothesis,$H_{0}{ }^{1}$ : The number of employees has changed significantly" is tenable (see Figure 6).

\section{Spearman's rank correlation rho}

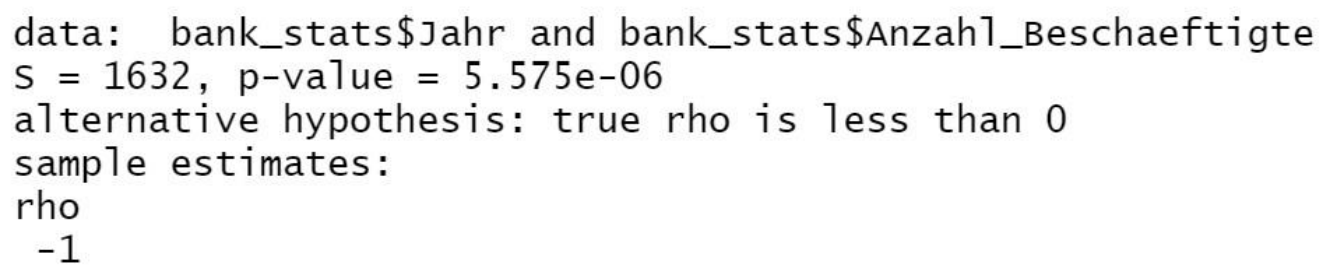

Figure 6: Own representation, significance test of the monotonic decrease in the number of employees in the years 2003 to 2019

The number of credit institutions developed similarly with a decline from originally just under 2500 institutions in 2013 to approx. 1700 institutions in 2019. Almost every third institution was closed in the period under review (see Figure 7).

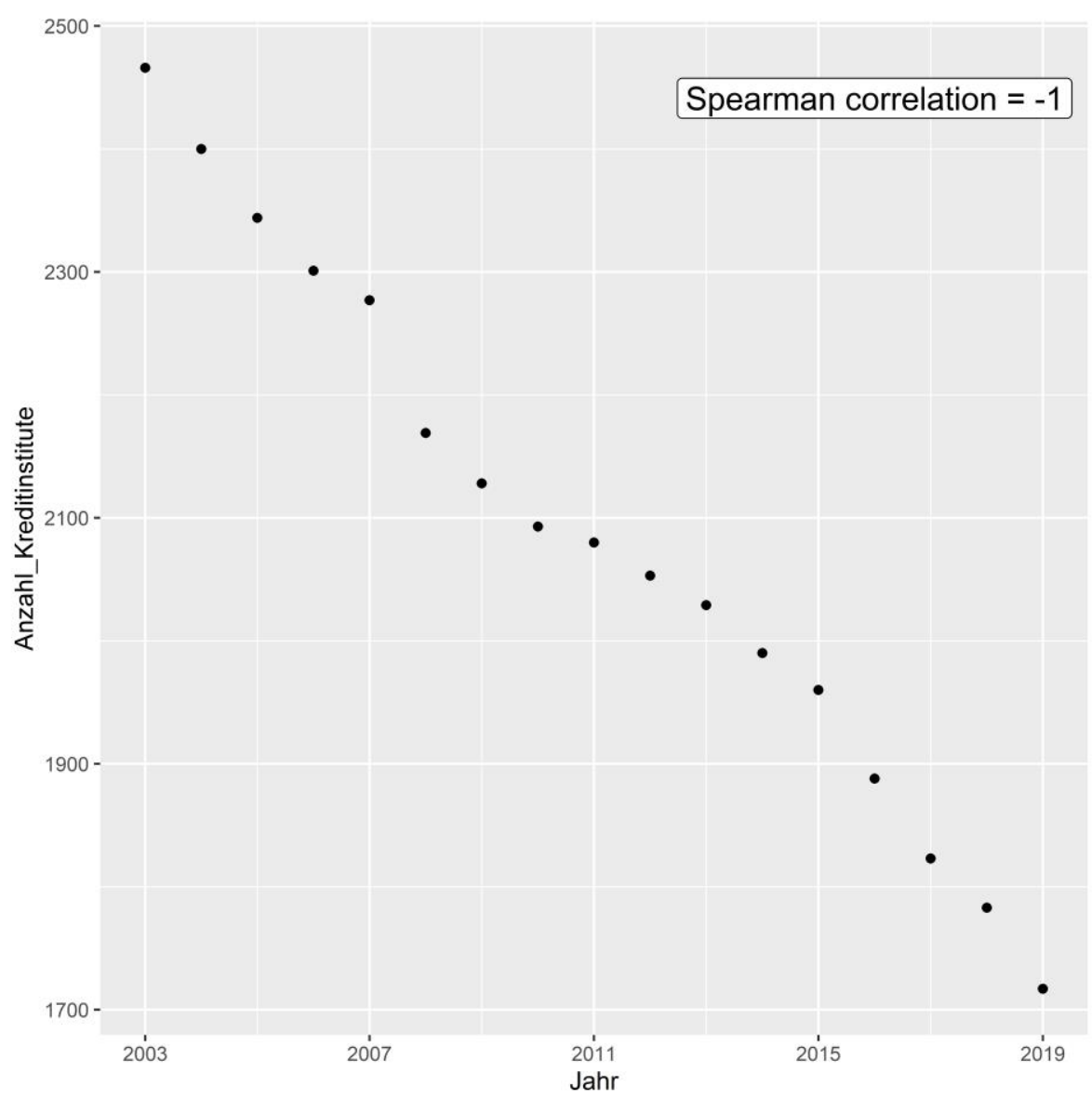

Figure 7: Own illustration, development of the number of credit institutions in the German bankingsector from 2003 to 2019

The decrease in the number of credit institutions is significant with a rank correlation coefficient of -1 and therefore the hypothesis „H$H_{0}^{2}$ : The number of credit institutions has changed significantly" can be accepted (see Figure 8).

$$
\text { Spearman's rank correlation rho }
$$

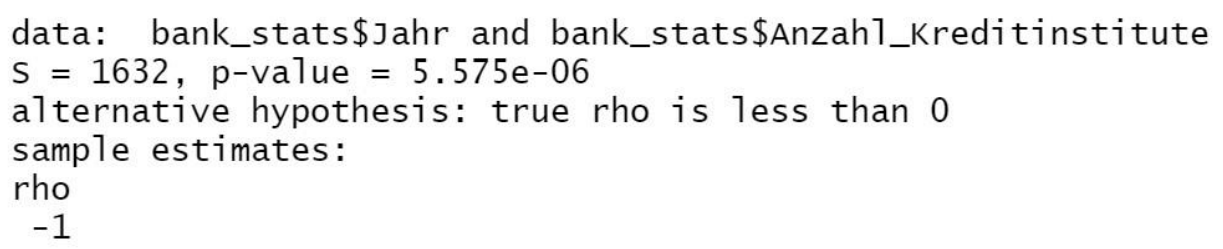


Figure 8: Own illustration, significance test of the monotonic decrease in the number of credit institutions in the years 2003 to 2019

The operating result was subject to strong annual fluctuations in the range of 30 billion euros throughout the entire period. The outlier in 2008, the year of the global financial crisis, with the only negative operating result in the period under review, is striking. Nevertheless, there was apparently no long-term trend in the operating result of the German banking industry, but rather a stagnation (see Figure 9).

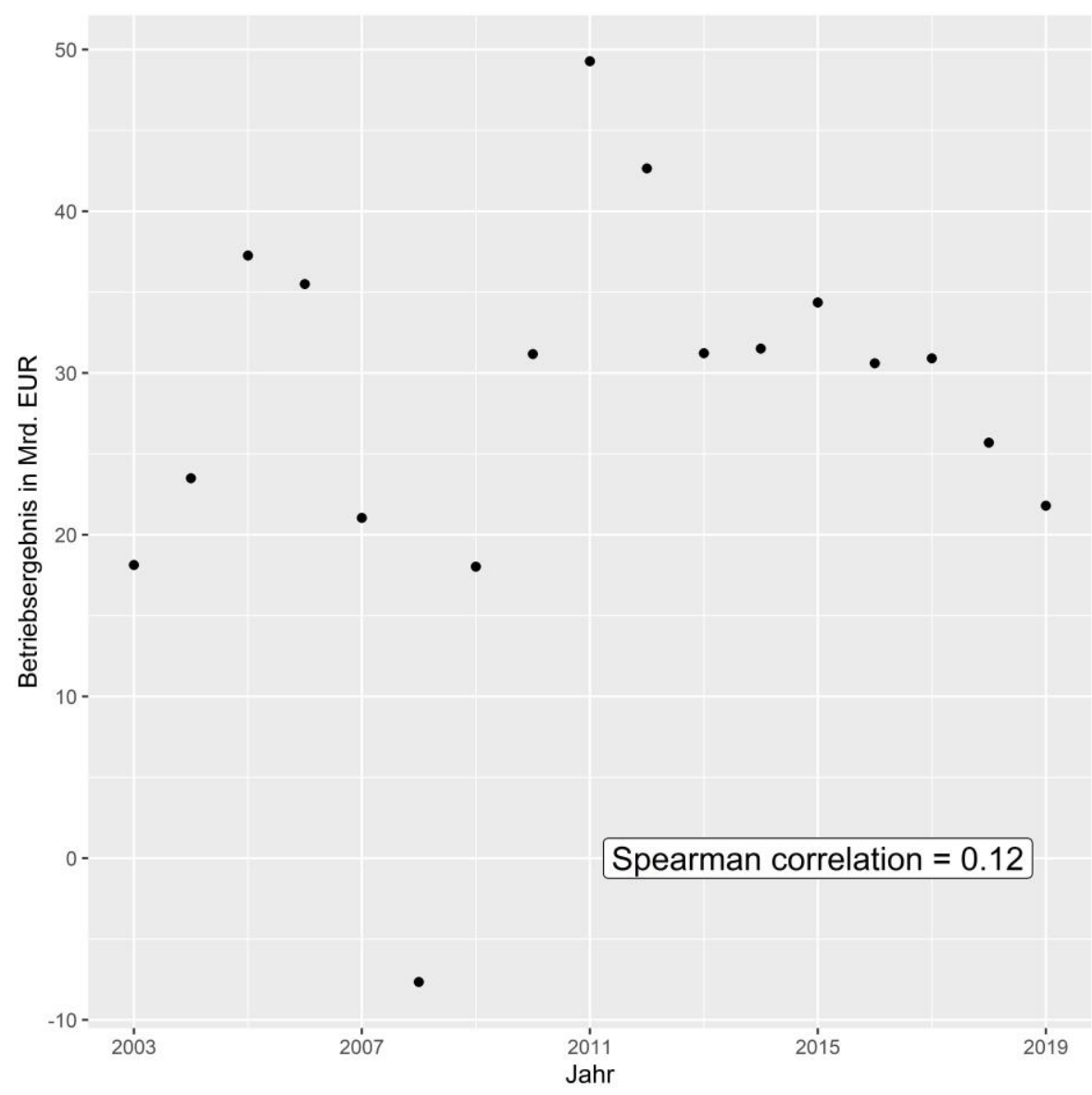

Figure 9: Own presentation, Development of the operating result in the German banking sectorfrom 2003 to 2019

The significance test shows that a slight monotonic increase in the operating result, implied by the rank correlation coefficient 0.12 , is not statistically significant. The p-value of 0.639 is greater than the defined significance level of 0.05 and thus the hypothesis „H$H_{0}$ : The operating result has changed significantly in the period under review" must be rejected (see Figure 10).

\section{Spearman's rank correlation rho}

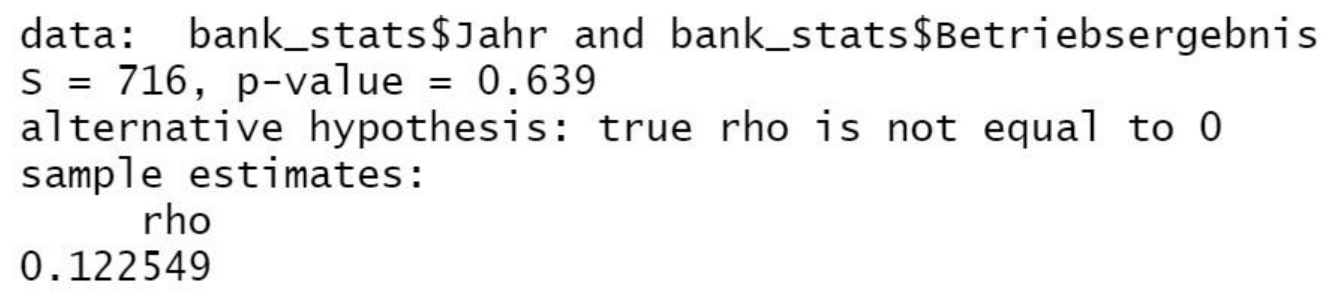

Figure 10: Own presentation, test for the existence of a temporal trend in the development of the operating result in the years 2003 to 2019

The balance sheet total increased strongly in the years up to 2011 - excluding the outlier in 2008 of the global financial crisis. This was followed in the early 2010s by a slump back to the levels of 2007 and 2009. By 2019, the balance sheet total had recovered again and almost reached its maximum in the period under review, with a recent sharp increase in 2019 (see Figure 11). 


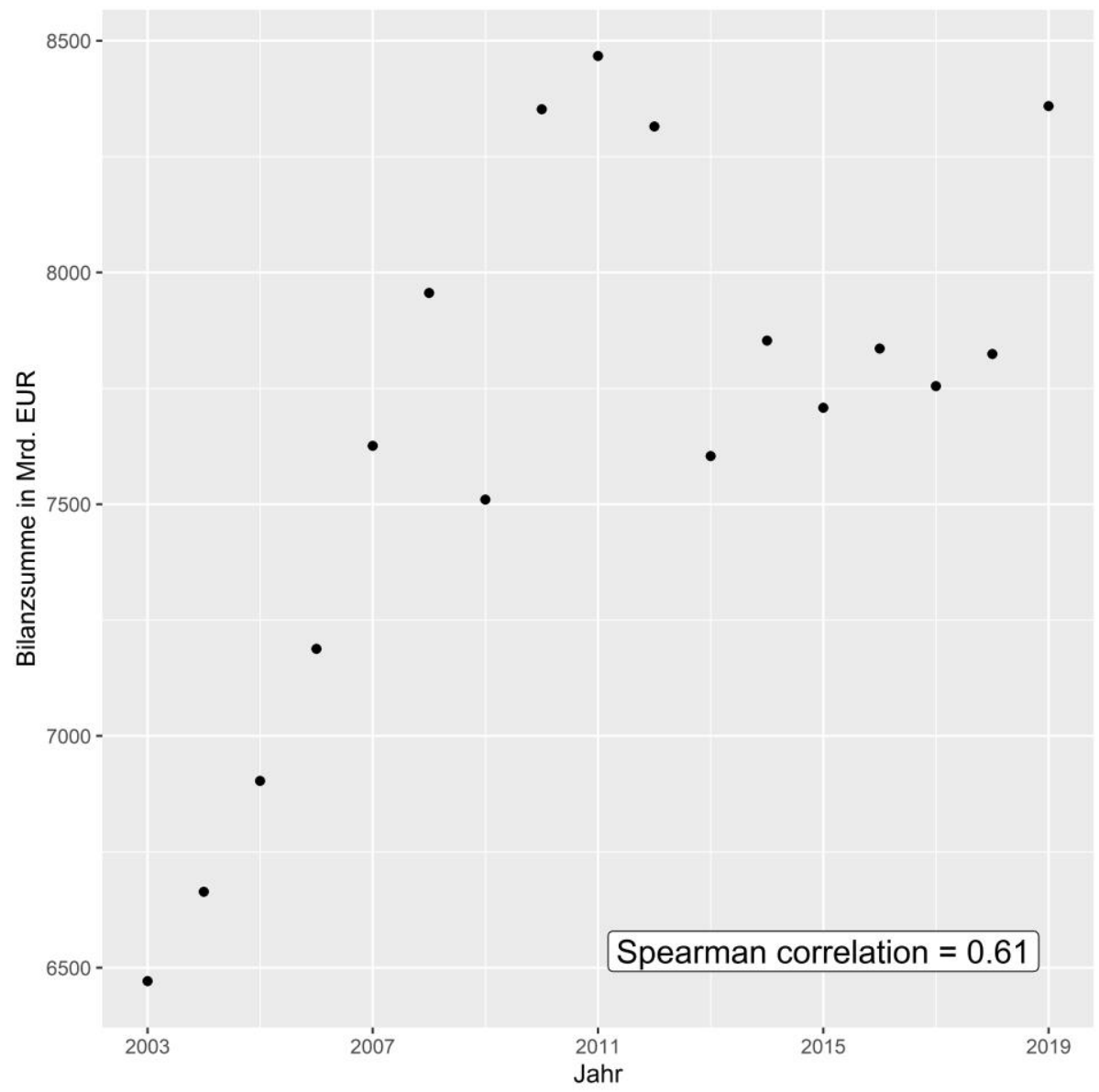

Figure 11: Own presentation, development of total assets in the German banking industry from2003 to 2019

The significant test result confirms the overall positive trend with which the balance sheet total has developed. The hypothesis,$H_{0}{ }^{4}$ : The balance sheet total has changed significantly" is tenable (see Figure 12).

\section{Spearman's rank correlation rho}

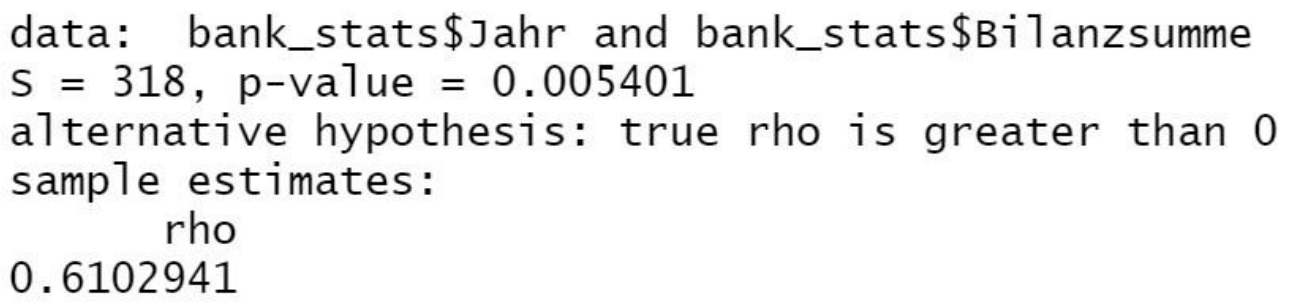

Figure 12: Own illustration, significance test of the monotonic increase in the balance sheet total in the years 2003 to 2019

After the cost-income ratio of the German banking sector improved nationwide by almost ten percentage points between 2003 and 2008 , the trend reversed from the global financial crisis onwards and reached its highest value in the period under review of $79.3 \%$ by 2019 (see Figure 13). 


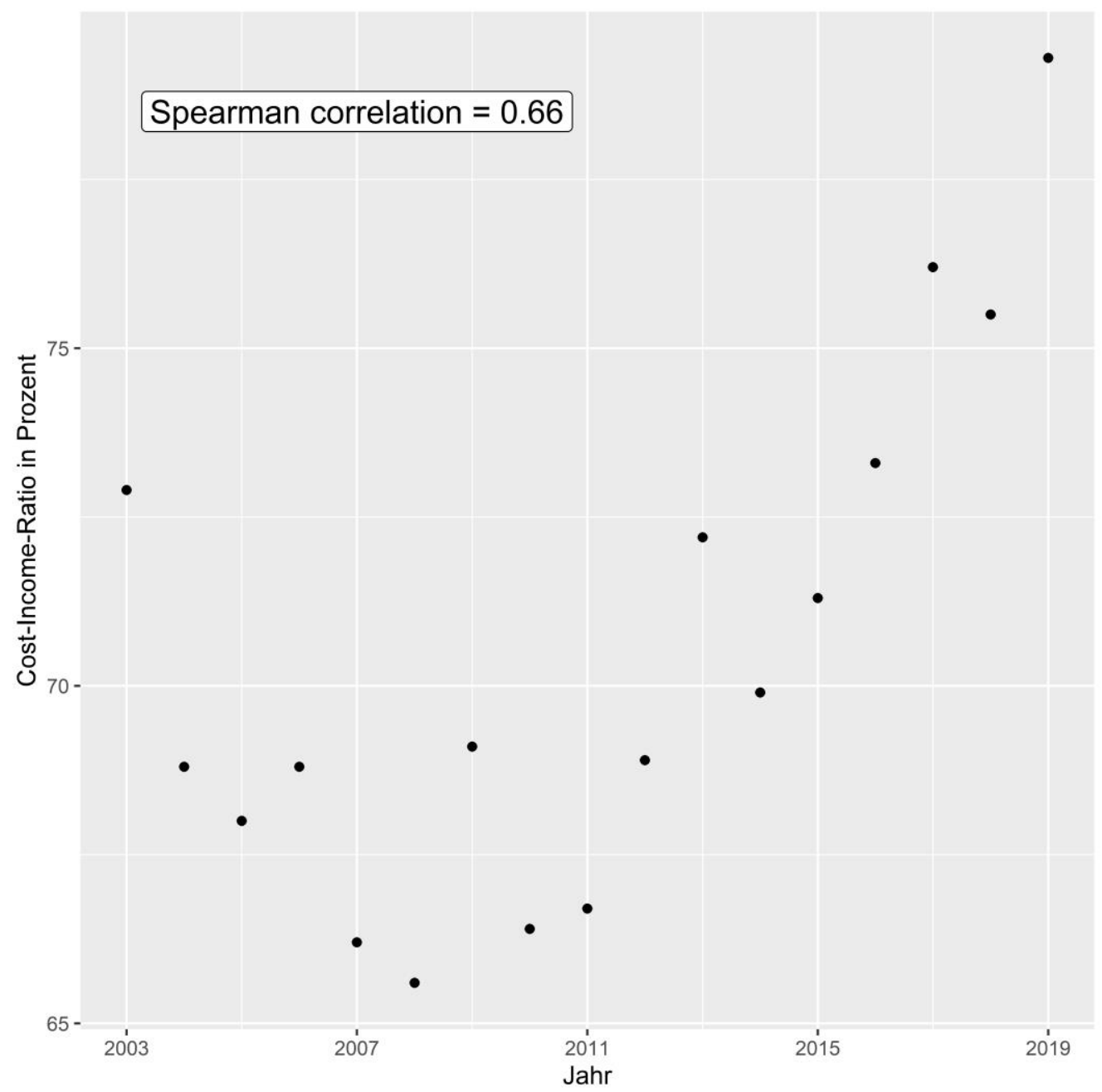

Figure 13: Own presentation, development of the cost-income ratio in the German banking industryfrom 2003 to 2019

The long-term trend towards a deterioration of the cost-income ratio is statistically significant and the hypothesis „, $H_{0}{ }^{5}$ : The cost-income ratio has changed significantly" is confirmed (see Figure 14).

Spearman's rank correlation rho

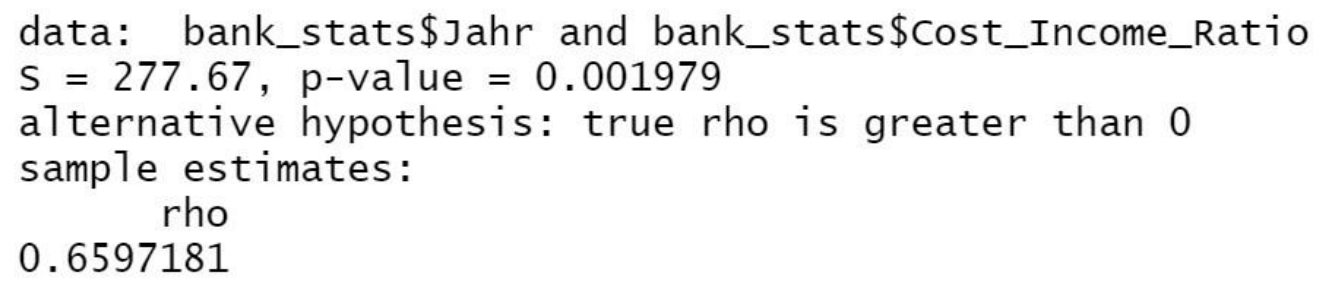

Figure 14: Own illustration, significance test of the monotonic increase in the cost-income ratio in the years 2003 to 2019

The final hypothesis ${ }_{\text {„H}} \mathrm{H}_{0}{ }^{6}$ : $\quad$ "H06: The use of big data analytics had a measurable influence on the developments of these indicators"s till need to be discussed in the light of the results and findings of the previous work.

\section{Influence of Big Data Analytics on the retail banking business of German banks}

The developments in the German banking sector in the years 2003 to 2019 have been examined on the basis of several key figures. It has been shown that the cost pressure in the banking sector described by Moormann has led to a consolidation of the banks, as can be seen from the continuous decline in the number of institutions and employees throughout the entire period under consideration. These observations are in line with the results of the authors Giebe and Schulz (2021c), who found an analogous development in the analysis of the savings banks and cooperative banks. They attribute these drastic measures to the banks' 


\section{"Big Data Analytics in the German Banking Sector Using the Example of Retail Banking"}

struggle for survival in a difficult market environment. The authors also criticise the lack of a concrete and sustainable business strategy that goes beyond cost-cutting measures. This could only succeed if investments in innovative technologies were pushed even more strongly in the sense of a digital strategy. The authors also include big data analytics (Giebe \& Schulz, 2021c).

However, the effectiveness of mere cost-cutting measures must also be discussed in the light of the operating result and the cost-income ratio. Although the cost side was steadily reduced by lowering the number of institutions and employees, the operating result did not improve significantly and the cost-income ratio even worsened considerably. This also raises the question of the effectiveness of Big Data analytics solutions in the German banking sector. As shown in this paper, big data analytics is already in use across banks and yet there was no trend reversal in the development of the cost-income ratio until 2019. A possible explanation for this observation is provided by the authors Hess and Francis. They collected the central points of criticism of the cost-income ratio as a metric for measuring the efficiency of a bank from a large number of publications. According to them, there is a "timing problem" in the recording of investments, for example in technologies, whose positive effects on the cost and income side occur with a time lag. At the time of measurement, these investments would unilaterally burden the cost side and thus drive up the cost-income ratio (Hess \& Francis, 2004; Osborne, 1995).

Including the development of the balance sheet total, this explanation seems plausible for the German banking market. As the analyses show, there was a significant increase in total assets between 2003 and 2019. Total assets grow, for example, when investments appear as liabilities on the liabilities side of a balance sheet, offset by assets such as Big Data infrastructure. However, it remains to be seen whether and when any Big Data analytics measures will have a positive impact on the German banking market. The hypothesis "H06: The use of big data analytics had a measurable influence on the developments of these key figures" cannot therefore be conclusively answered within the scope of this project work with the given data. The renewed investigation of the indicators at a later point in time offers itself as a starting point for future research in this area.

\section{CONCLUSIONS}

Since 2000, the influence of new digital technologies has had a major impact. Digital transformation describes the integration of digital technologies into business processes (Liu et al., 2011). In many sectors, from industry to science, a digital transformation can be observed along the various value chains. Here, companies are increasingly relying on information-based stimuli to promote innovation, solve problems and improve processes (Kauffmann \& Weber, 2018). In this context, the use of big data analytics is repeatedly discussed and use cases experimented with.

The German banking sector has all the prerequisites for a successful implementation of Big Data Analytics in business processes. In retail banking, this potential is already being realised across banks, so that data analytics selections are used across many financial products when selecting customers for sales campaigns. The complete sales orientation towards an integrated omnichannel strategy, in which each customer can contact the bank individually via the channel that suits him or her, is a possible next development step. It can be supported by the consistent integration of data analytics to determine the most suitable approach channel in each case.

The technological developments in the German banking market are, however, embedded in a market environment that is characterised by growing customer demands and strong competition from FinTechs and non-banks in established business areas as well as a generally unfavourable interest rate environment. As shown in this paper, the resulting cost pressure leads to drastic cost-cutting measures such as staff reductions and the merger or closure of institutions. At the same time, the operating profit from the operational banking business is stagnating and the cost-income ratio - a measure of a bank's efficiency - has deteriorated sharply in recent years. A positive effect of Big Data analytics applications by 2019 could not be measured and yet there is talk in the management of the banks about lifting the treasure trove of data, which seems paradoxical at first. This paradox was finally resolved by working out that improvements in key figures such as the cost-income ratio and the operating result only occur with a time lag when investments are made in technologies, as the costs are not initially offset by any immediate added value. The sales departments of banks need time until all sales measures are aligned with the consistent integration of data analytics methods and the processes are understood. In addition, technical solutions for the integration of all systems into a digital sales strategy still have to be created in some cases.

A company's digital strategy only has added value if it bundles resources and promotes investments. Many companies are rather hesitant in defining a digital strategy. However, the best digital strategies guided operational decisions and strategic choices at the 


\section{"Big Data Analytics in the German Banking Sector Using the Example of Retail Banking"}

same time (Sebastian et al., 2017).

The bottom line is that digitalization is not a project that ends at some point. Digitalization is a process that accompanies banks from now on and needs intelligent implementation strategies. Digitisation will become a natural part of the daily work in the organisation. How successful a change management process will be with regard to digitalization therefore depends to a large extent on the willingness of the banks in Germany to change. This can only be achieved through education, awareness-raising and the development of strategies that involve and empower all employees (Giebe, 2019).

\section{Limits and directions for further research}

This results in an interesting opportunity for future research in this area. If the potential of big data analytics has actually been realised across all banks, this will be reflected in a positive change in the key figures considered. In particular, the cost-income ratio should stabilise and improve again in the foreseeable future, and the investments made in Big Data infrastructure will have paid for themselves. From this point of view, it seems sensible to re-evaluate the analysed developments at a later point in time in order to finally answer the question about the effectiveness of Big Data Analytics in the German banking market.

Due to demographic change and the poor image, German banks are getting fewer and fewer young professionals. At first glance, they are therefore not considered attractive employers. Moreover, young adults are aware of this situation and make different demands on their future jobs than previous generations. The so-called Generation Z (born between 1995 and 2010) is described as enormously tech-savvy and is very digitally savvy (Löffler \& Giebe, 2021). This circumstance could be examined directly under Big Data Analytics aspects. For example, what specific contribution do Generation Z employees attribute to big data analytics projects?

As far as the need for qualification is concerned, regardless of the age of the bank employees, the demands on the social competence of the workforce increase again in the digital age. On the other hand, many years of professional experience with its positive advantages, such as increased soft and communication skills, are being questioned. The need for employees with strong communication skills and a high willingness to cooperate can be seen (Hammermann \& Stettes, 2016). This suggests another research gap for investigation.

The two main development streams are external digitalization in the context of changing employee-customer contact and internal digitalization with new internal processes and communication channels within a bank or savings bank. A real competitive advantage can be generated through a successful link between the classic attitudes of an advisor and the opportunities of digitalization (Damaschke \& Giebe, 2020). Here, the authors recommend further research with the aim of working out concrete recommendations for action in order to bring these two perspectives together profitably from different points of view.

\section{Availability of data and materials}

In order to make the developments on the German banking market measurable until 2019, data from the statistics portal "Statista" was used. Data is available on the development of the number of employees, the number of credit institutions, the operating result, the balance sheet total and the cost-income ratio. The operating result shows the result from the ordinary business activities of a bank. This includes, in particular, interest from lending and the sale of financial products. The cost-income ratio provides information on the efficiency of a bank by comparing income with expenses. A low cost-income ratio generally stands for an efficient bank (Osborne, 1995). These ratios are already available for download and cover different time periods, in particular not all of them extend into the year 2020. Consequently, they have been limited to the common observation period 2003 to 2019. Based on the analysis of these key figures in accordance with the hypotheses, the developments in the banking market will be empirically examined with the aim of highlighting the influence of digitalisation and big data analytics.

\section{REFERENCES}

1. Arts, V. (2016). Aktuelle Herausforderungen für Genossenschaftsbanken: Eine Analyse der Umwelt [Current challenges for cooperative banks: An analysis of the environment]. Arbeitspapiere des Instituts für Genossenschaftswesen der Westfälischen Wilhelms-Universität Münster (No. 163), http://hdl.handle.net/10419/129624

2. Au, CD. \& Hiese, A. (2021). Künstliche Intelligenz in Banken: Worauf es im aktuellen Marktumfeld ankommt [Artificial intelligence in banks: What matters in the current market environment]. Digitale Welt 5, 26-29. 
"Big Data Analytics in the German Banking Sector Using the Example of Retail Banking" https://doi.org/10.1007/s42354-021-0359-z

3. Behr, P. \& Schmidt, R. (2015). The German banking system: Characteristics and challenges, SAFE White Paper, No. 32, Goethe University Frankfurt a. M. http://hdl.handle.net/10419/129081

4. Conrad, A., Hoffmann, A., \& Neuberger, D. (2017). Physische und digitale Erreichbarkeit von Finanzdienstleistungen der Sparkassen [Physical and digital accessibility of financial services of savings banks], ThünenSeries of Applied Economic Theory - Working Paper, No. 149, Universität Rostock, Institut für Volkswirtschaftslehre, Rostock, http://hdl.handle.net/10419/156222

5. Damaschke, C. (2020). Gut - heute und in der Zukunft [Good - today and in the future], SparkassenZeitung, VERTRIEB, Sparkassen Data Analytics. Retrieved from: https://www.sparkassenzeitung.de/vertrieb/sparkassen-dataanalytics-gut-heute-und-der-zukunft [Accessed December 2021]

6. Damaschke, C. \& Giebe, C. (2020), Sparkassen-DataAnalytics: Den Datenschatz der Sparkassen-Finanzgruppe heben [Sparkassen-DataAnalytics: Lifting the Data Treasure of the Savings Banks Finance Group], In: Erich R. Utz, Digitalisierung - "the next challenge" für Sparkassen Handlungsfelder zur künftigen Gestaltung des Geschäftsmodells in Sparkassen (pp. 139-154). Deutscher Sparkassenverlag, Stuttgart.

7. Deutsche Bundesbank (2021). Zahlungsverkehrs- und Wertpapierabwicklungsstatistiken [Payments and securities settlement statistics]. Retrieved from: https://www.bundesbank.de/resource/blob/804036/824fb3c61a0dff6cba57 d6d5d154a821/mL/i- zahlungsver kehrsstatistik-data.pdf [Accessed December 2021]

8. Drummer, D., Jerenz, A., Siebelt, P., \& Thaten, M. (2016). Challenges and opportunities for fintech in Germany How digitization is transforming the country's financial services sector. McKinsey \& Company, (May), 1-7. Retrieved from: http://www.mckinsey.com/industries/financial-services/our-insights/fintech-challenges-and-opportunities [Accessed December 2021]

9. Giebe, C. (2019). The Chief Digital Officer-Savior for the Digitalization in German Banks?. Journal of Economic Development, Environment and People, 8(3), 6-15, http://dx.doi.org/10.26458/jedep.v8i3.633

10. Giebe, C., Hammerström, L., Zwerenz, D. (2019). Big Data \& Analytics as a sustainable Customer Loyalty Instrument in Banking and Finance. Financial Markets, Institutions and Risks, 3(4), 74-88. http://doi.org/10.21272/fmir.3(4).74-88.2019

11. Giebe, C., \& Schulz, K. (2021a). Cost Cutting Measures at Cooperative Banks in Germany as a Result of Digitalization and their Consequences. Journal of Economic Development, Environment and People, 10(2), 29-45. https://dx.doi.org/10.26458/jedep.v10i2.693

12. Giebe, C. \& Schulz, K. (2021b). Digitalization and its Rapid Impact on Savings Banks in Germany. Global Journal of Management and Business Research, 21(4), 1-11, https://doi.org/10.34257/GJMBRBVOL21IS4PG1

13. Giebe, C. \& Schulz, K. (2021c). Economic Effects of the Digital Transformation on the Banking Market Using the Example of Savings Banks and Cooperative Banks in Germany. International Journal of Economics and Finance, 13(6), 34-45. https://doi.org/10.5539/ijef.v13n6p34

14. Gronau, N., Thim, C., \& Fohrholz, C. (2016). Business Analytics in der deutschen Praxis [Business Analytics in der deutschen Praxis.]. Controlling, 28(8-9), 472-479. https://doi.org/10.15358/0935-0381-2016-8-9-472

15. Hammermann, A., \& Stettes, O. (2016). Qualifikationsbedarf und Qualifizierung: Anforderungen im Zeichen der Digitalisierung [Skills needs and qualification: requirements in the spirit of digitalisation]. IW policy paper (No. 3/2016). Institut der deutschen Wirtschaft (IW). German Economic Institute, http://hdl.handle.net/10419/127450

16. Hammerström, L. (2018). Organizational Design of Big Data and Analytics Teams. European Journal of Social Science Education and Research, 5(3), 132-149. https://doi.org/10.2478/ejser-2018-0065

17. Hammerström, L., Giebe, C., Zwerenz, D. (2019). Influence of Big Data \& Analytics on Corporate Social Responsibility. SocioEconomic Challenges, 3(3), 47-60.

18. Hess, K., \& Francis, G. (2004). Cost income ratio benchmarking in banking: a case study. Benchmarking: An International Journal, 11(3), 303-319. https://doi.org/10.1108/14635770410538772

19. IDC (2020). Asia/Pacific Big Data Analytics Solutions' Revenue Will Increase by US\$ 41.9 billion by 2024, IDC Reports. Retrieved from: https://www.idc.com/getdoc.jsp?containerId=prAP47297621 [Accessed December 2021]

20. Kauffman, R. J., Weber, T. A. (2018). Special Section: The Digital Transformation of Vertical Organizational 
"Big Data Analytics in the German Banking Sector Using the Example of Retail Banking"

Relationships, Journal of Management Information Systems, 35(3), 837-839,

https://doi.org/10.1080/07421222.2018.1481646

21. Komorowski, Piotr (2020), Role of digitization for German saving banks, In: Erich R. Utz, Digitalisierung - "the next challenge" für Sparkassen Handlungsfelder zur künftigen Gestaltung des Geschäftsmodells in Sparkassen (pp. 329-345). Deutscher Sparkassenverlag, Stuttgart.

22. Kramer \& Mendez Inclan (2019). Data Analytics im Privatkundenvertrieb deutscher Retail-Banken [Data analytics in private customer sales of German retail banks], KPMG-Research. Retrieved from:

https://home.kpmg/de/de/home/themen/2019/11/retail-banken-data-analytics-privatkunden.html [Accessed December 2021]

23. Lange, M. (2020): Abschlussquoten steigern [Increase completion rates], SparkassenZeitung, VERTRIEB, Sparkassen Data Analytics. Retrieved from:

https://www.sparkassenzeitung.de/vertrieb/sparkassen-data-analytics-abschlussquoten-steigern [Accessed

December 2021]

24. Liu, D. Y., Chen, S. W., \& Chou, T. C. (2011). Resource fit in digital transformation: Lessons learned from the CBC Bank global e-banking project. Management Decision, 49(10), 1728-1742, https://doi.org/10.1108/00251741111183852

25. Löffler, L. \& Giebe, C. (2021). Generation $Z$ and the War of Talents in the German Banking Sector. International Journal of Business Management and Economic Review, 4(6), 1-18, http://doi.org/10.35409/IJBMER.2021.3319

26. Menrad, M. (2020). Systematic review of omni-channel banking and preview of upcoming developments in Germany. Innovative Marketing , 16(2), 104-125, https://doi.org/10.21511/im.16(2).2020.09

27. Moormann, J. (2000). Die Digitalisierung des Bankgeschäfts [The digitization of banking business]. In Informationstechnologie in Banken (pp. 3-16). Springer, Berlin, Heidelberg, https://doi.org/10.1007/978-3-642-56991-3_1

28. Osborne, J. (1995). A Case Of Mistaken Identity: The Use Of Expense/Revenue Ratios To Measure Ratios To Measure Bank Efficiency. Journal of Applied Corporate Finance, 8(2), 55-59. https://doi.org/10.1111/j.1745-6622.1995.tb00287.x

29. S Rating und Risikosysteme GmbH (2021). Kundenberatung verbessern: SparkassenData-Analytics [Improving customer advice: SparkassenData-Analytics aka Savings Banks Data-Analytics.]. Retrieved from:

https://www.s-rating-risikosysteme.de/Unser_Aufgabenspektrum/Data_Analytics.html [Accessed December 2021]

30. Schädle, T.H. (2021) Die Besonderheiten der deutschen Kreditwirtschaft. In: Abwicklung nicht-systemrelevanter Banken. Springer Gabler, Wiesbaden. https://doi.org/10.1007/978-3-658-32488-9_2

31. Sebastian, I., Ross, J., Beath, C., Mocker, M., Moloney, K., \& Fonstad, N. (2017). How big old companies navigate digital transformation. MIS Quarterly Executive 16 (3), 197-213, https://aisel.aisnet.org/misqe/vol16/iss3/6

32. Statista Research Department (2020). Anzahl der Beschäftigten im deutschen Kreditgewerbe in den Jahren von 1991 bis 2019 [Number of employees in the German banking industry in the years from 1991 to 2019].

https://de.statista.com/statistik/daten/studie/6786/umfrage/anzahl-der-beschaeftigten-im-bankgewerbe/

[Accessed December 2021]

33. Statista Research Department (2021). Betriebsergebnis der Banken in Deutschland von 1999 bis 2019 (in Milliarden Euro) [Operating result of banks in Germany from 1999 to 2019 (in billions of euros)].

https://de.statista.com/statistik/daten/studie/467034/umfrage/betriebsergebnis-der-banken-in-deutschland/

[Accessed December 2021]

34. Statista Research Department (2021).Cost-Income-Ratio der Banken in Deutschland in den Jahren von 1998 bis 2019 [Cost-income ratio of banks in Germany in the years from 1998 to 2019].

https://de.statista.com/statistik/daten/studie/309572/umfrage/cost-income-ratio-der-banken-in-deutschland/

Accessed December 2021]

35. Statista Research Department (2021). Anzahl der Kreditinstitute in Deutschland in den Jahren von 1957 bis 2020

[Number of credit institutions in Germany in the years from 1957 to 2020].

https://de.statista.com/statistik/daten/studie/36315/umfrage/anzahl-der-kreditinstitute-in-deutschland-seit-20 03/

[Accessed December 2021]

36. Statista Research Department (2021). Entwicklung der Bilanzsumme der deutschen Bankenbranche von 2000 bis 2020 
"Big Data Analytics in the German Banking Sector Using the Example of Retail Banking"

(in Milliarden Euro) [Development of the balance sheet total of the German banking industry from $\quad 2000$ to 2020 (in billions of euros)].

https://de.statista.com/statistik/daten/studie/187500/umfrage/entwicklung-der-bilanzsumme-der-banken-in-deutschland-se it-2003/ [Accessed December 2021]

37. Statista Research Department (2020).Marktanteile der Bankengruppen in Deutschland nach dem Geschäftsvolumen im Jahr 2020 [Market shares of the banking groups in Germany by business volume in 2020].

https://de.statista.com/statistik/daten/studie/161141/umfrage/marktanteile-von-bankengruppen-in-deutschland-nachgeschaeftsvolumen/\#professional [Accessed December 2021]

38. Trelewicz, J. Q. (2017). Big data and big money: The role of data in the financial sector. IT professional, 19(3), 8-10. https://doi.org/10.1109/MITP.2017.45

39. Wolgast, M. (2016). Das gegenwärtige Niedrigzinsumfeld aus Sicht der Sparkassen [The current low interest rate environment from the point of view of savings banks]. Vierteljahrshefte zur Wirtschaftsforschung, 85(1), 11-29, https://doi.org/10.3790/vjh.85.1.11

\section{Corresponding Author: Carsten Giebe}

Hungarian University of Agriculture and Life Sciences, Kaposvár Campus - Faculty of Economic Science, Guba Sándor u. 40, H-7400 Kaposvár, Hungary 